\title{
Effect of temozolomide on cell viability in gonadotroph adenoma cell lines
}

\author{
SIHAI MA ${ }^{1}$, XIAOHAI LIU $^{1}$, YONG YAO $^{1}$, FENG CAI $^{1}$, CONGXIN DAI $^{1}$, XINJIE BAO $^{1}$, \\ MING FENG ${ }^{1}$, JUNJI WEI ${ }^{1}$, BO ZHANG ${ }^{2}$, GUILIN LI $^{1}$, WENBIN MA ${ }^{1}$ and RENZHI WANG ${ }^{1}$ \\ ${ }^{1}$ Department of Neurosurgery, Peking Union Medical College Hospital, Chinese Academy of Medical \\ Sciences and Peking Union Medical College, Beijing 100730; ${ }^{2}$ Department of Neurosurgery, \\ The First Affiliated Hospital of Dalian Medical University, Dalian 116011, P.R. China
}

Received March 24, 2011; Accepted April 27, 2011

DOI: $10.3892 /$ or.2011.1317

\begin{abstract}
Invasive pituitary adenomas are usually refractory to routine neurosurgery, radiosurgery or medications, and alternative therapies are needed. The effects of temozolomide (TMZ) on the inhibition of gonadotroph adenoma cell viability and hormone secretion were evaluated. Cell viability and $\mathrm{IC}_{50}$ values were evaluated after $\alpha \mathrm{T} 3-1$ cells were treated with TMZ (31.25-1000 $\mu \mathrm{M})$ or vehicle for 0-72 h. Cell cycle changes and the extent of apoptosis were detected using flow cytometry, TUNEL and TEM. The molecular mechanism of TMZ action was investigated by the Caspase-Glo ${ }^{\circledR}$ assay and immunoblotting. Gonadotropin secretion was assessed using an immunoassay system. TMZ dose- and time-dependently suppressed cell proliferation $(\mathrm{P}<0.01 \mathrm{vs}$. control, $250 \mu \mathrm{M}$, $24 \mathrm{~h})$ and induced S-phase accumulation and G2/M-phase arrest ( $\mathrm{P}<0.05$ vs. control, $250 \mu \mathrm{M}, 24 \mathrm{~h})$. Early apoptotic cells increased following a $24-\mathrm{h}$ TMZ incubation $(\mathrm{P}<0.001$ vs. control, $250 \mu \mathrm{M})$, consistent with TEM and TUNEL detection that exhibited morphological features of apoptosis. TMZ $(250 \mu \mathrm{M})$ increased the level of caspase-3/7 by 6 -fold, caspase- 9 by 7 -fold and caspase- 8 by 3 -fold after a 24 -h incubation, while it attenuated $\mathrm{Bcl}-2$ expression $(\mathrm{P}<0.001$ vs.
\end{abstract}

Correspondence to: Dr Renzhi Wang, Department of Neurosurgery, Peking Union Medical College Hospital, Chinese Academy of Medical Sciences and Peking Union Medical College, Beijing 100730, P.R. China

E-mail:wrzpumch@yahoo.cn

Abbreviations: CCK-8, cell counting kit-8; DSBs, double-strand breaks; $\mathrm{IC}_{50}$, median inhibitory concentration; $\mathrm{FSH}$, follicle-stimulating hormone; LH, luteinizing hormone; MGMT, $O^{6}$-methylguanine-DNA methyltransferase; NFPAs, non-functioning pituitary adenomas; $O^{6} \mathrm{MeG}, O^{6}$-methylguanine; PARP, poly(ADP-ribose) polymerase; PBS, phosphate-buffered saline; RLU, relative light units; TEM, transmission electron microscope; TUNEL, terminal deoxynucleotidyltransferase-mediated deoxyuridine triphosphate nick-end labeling

Key words: gonadotroph adenoma, $\alpha \mathrm{T} 3-1$, temozolomide, apoptosis control) and raised the proteolysis of PARP. Both FSH and LH levels were significantly decreased by $\mathrm{TMZ}(\mathrm{P}<0.01$ vs. control, $250 \mu \mathrm{M}, 24 \mathrm{~h}$ ). TMZ inhibited cell proliferation and hormone secretion, and induced cell cycle arrest and apoptotic cell death in gonadotroph adenoma cells via both death receptor and mitochondrial pathways, suggesting that it may represent a useful medical management strategy of invasive gonadotroph adenomas.

\section{Introduction}

Pituitary adenomas account for nearly $15 \%$ of clinical intracranial neoplasms (1), with autopsy studies demonstrating an incidence of $25 \%$ (2). Gonadotroph tumors comprise $15-35 \%$ of all pituitary adenomas, and most of the clinically non-functioning adenomas, which constitute approximately one-third of all tumors of the anterior pituitary, are actually gonadotropin-secreting adenomas or gonadotroph adenomas (3-5). Although most gonadotroph adenomas are benign, slow-growing tumors, some are characterized by fast invasive growth, increased mitotic activity, a Ki-67 labeling index greater than $3 \%$, and positive p53 immunoreactivity (6). These patients generally consult for headache and/or a visual field disorder, and baseline concentrations of gonadotropins or their free subunits are elevated in $30-50 \%$ of these patients (7). These tumors are refractory to neurosurgery, radiosurgery or alternative medical therapies (such as dopaminergic agonists, somatostatin analogs, and GnRH agonists/antagonists) (7). There is an urgent need to identify new therapeutic targets and develop new agents for the treatment of these refractory adenomas.

TMZ, one of the alkylating chemotherapeutic agents, has been approved for the treatment of patients with metastatic melanoma and glioblastoma multiforme (8). In addition, TMZ clinical trials have been performed to test its activity against brain metastatic solid tumors, leukemia (8), pancreatic neuroendocrine tumors (9) and refractory pituitary adenomas (10-14). Two case studies related to gonadotroph adenoma patients report that their lesions decreased after TMZ therapy $(15,16)$, and studies of TMZ on MMQ, GH3, and AtT20 cell lines suggested that this drug may have efficacy in pituitary adenoma cells (17). However, in another study, TMZ failed 
to attain biochemical control in a severe case of acromegaly (18). These conflicting data prompted us to further study the effectiveness and mechanism of TMZ on pituitary adenoma cell death in detail. In this study, the effects of TMZ on cell viability, apoptosis, and gonadotropin secretion are assessed in the mouse gonadotroph adenoma cell line, $\alpha \mathrm{T} 3-1$, which is derived from a transgenic mouse and maintains differentiated functions unique to gonadotropes (19).

\section{Materials and methods}

Chemicals and reagents. TMZ was obtained from SigmaAldrich (Shanghai, China). The cell counting kit (CCK)-8 was obtained from Dojindo Laboratories (Kumamoto, Japan). The DeadEnd ${ }^{\mathrm{TM}}$ Fluorometric TUNEL System and the Caspase-Glo ${ }^{\circledR}$ 3/7, 8 and 9 assay systems were supplied by Promega (Beijing, China). Annexin V-FITC apoptosis assay kit was provided by Biosea Biotechnology (Beijing, China).

Cell culture. The $\alpha \mathrm{T} 3-1$ cells used in this study were kindly provided by Dr P.L. Mellon (Department of Reproductive Medicine, University of California, San Diego, CA) and were maintained in monolayer cultures in DMEM supplemented with $10 \%$ fetal bovine serum, $100 \mathrm{U} / \mathrm{ml}$ penicillin $\mathrm{G}$ and $0.1 \mathrm{mg} / \mathrm{ml}$ streptomycin (Invitrogen, China) in humidified $5 \% \mathrm{CO}_{2}, 95 \%$ air, at $37^{\circ} \mathrm{C}$. The cells were passaged at $\sim 90 \%$ confluence using a trypsin-EDTA solution (0.05\% trypsin, $0.5 \mathrm{mM}$ EDTA). Cells were kept in phenol red-free medium containing charcoal-treated fetal bovine serum for 4 days before the experiments.

Drug treatment and assessment of cell viability. The $\alpha \mathrm{T} 3-1$ cells were trypsinized, centrifuged and resuspended in $1 \mathrm{ml}$ of medium, then plated in 96 -well plates at $1 \times 10^{4}$ cells $/ 100 \mu 1$ per well. After incubation for $24 \mathrm{~h}, \mathrm{TMZ}(31.25,62.5,125,250,500$ or $1000 \mu \mathrm{M}$ ) was added to the respective wells, with DMSO serving as solvent control. Cell viability was evaluated every $24 \mathrm{~h}$ by the CCK- 8 assay. Briefly, $10 \mu \mathrm{l}$ of CCK- 8 was added to each well followed by incubation at $37^{\circ} \mathrm{C}$ for $3 \mathrm{~h}$. Absorbance was then measured at a wavelength of $450 \mathrm{~nm}$ using a Victor-2 plate reader (Perkin Elmer). Each CCK-8 assay was performed in triplicate. Cell viability was calculated as a percentage of the control, and the median inhibitory concentration $\left(\mathrm{IC}_{50}\right)$ of TMZ were calculated from growth inhibition curves fitted to the data using the OriginPro 7.5 software (OriginLabs, Northampton, MA, USA).

Cell cycle analysis. Cell cycle distribution was determined by staining DNA with propidium iodide (PI). Briefly, $\alpha \mathrm{T} 3-1$ cells were treated with TMZ or DMSO for 24-48 $\mathrm{h}$ and then harvested. Cells were then washed and fixed in $70 \%$ ethanol on ice for $30 \mathrm{~min}$. After centrifugation, the cell pellets were washed and resuspended in phosphate-buffered saline (PBS). Cells were then treated with RNase and stained with PI. DNA content was analyzed using a FACS flow cytometer (BectonDickinson).

Annexin V staining. $\alpha \mathrm{T} 3-1$ cells were seeded at $1 \times 10^{5}$ cells/ well in 6-well plates and treated with 125,250 or $500 \mu \mathrm{M}$ TMZ, or DMSO after cells were grown to $50 \%$ confluence.
After drug or vehicle incubation for $24 \mathrm{~h}$, Annexin $\mathrm{V}$ assays were performed according to the manufacturer's protocol (Biosea, China). Briefly, the cultured cells were trypsinized and collected, washed twice with PBS and resuspended with $200 \mu \mathrm{l}$ binding buffer before addition of $10 \mu \mathrm{l}$ of Annexin-VFITC. After a 15-min incubation at room temperature in the dark, nuclei were counterstained with $5 \mu \mathrm{l}$ PI (Sigma). The percentage of apoptotic cells was determined using a FACS flow cytometer.

TUNEL staining. $\alpha \mathrm{T} 3-1$ cells were cultured on glass-bottomed dishes (Nest Biotechnology Corporation) at a density of $2 \times 10^{4}$ cells/well. After cells were grown to $50 \%$ confluence, the cells were treated with $125,250,500,1000 \mu \mathrm{M}$ TMZ or DMSO. Treatment was terminated at $24 \mathrm{~h}$, and the cells were fixed in $4 \%$ methanol-free formaldehyde in PBS for $25 \mathrm{~min}$. TUNEL staining was performed for detection of apoptotic cells using the fluorometric TUNEL staining kit (Promega Corporation, Madison, WI). In brief, the fixed cells were washed twice in PBS and permeabilized with $0.2 \%$ Triton X-100 for $5 \mathrm{~min}$. The cells were again washed twice in PBS, equilibrated with the equilibration buffer at room temperature for $5 \mathrm{~min}$ and then incubated with $50 \mu \mathrm{l}$ of TdT fluorescein-12-dUTP for $1 \mathrm{~h}$ at $37^{\circ} \mathrm{C}$ in a humidified chamber. The reaction was terminated by 2X SSC for $15 \mathrm{~min}$ at room temperature and slides were washed three times in PBS and mounted with anti-fading mounting medium (Golden Bridge International, Inc., Mukilteo, WA, USA). The cells were observed and photographed under a confocal microscope (Zeiss, Heidelberg, Germany).

Electron microscopy. Following a 24-h treatment with TMZ $(250 \mu \mathrm{M})$, cell samples were collected and fixed in $2.5 \%$ glutaraldehyde and post-fixed in $1 \%$ osmium tetroxide. After dehydration in graded ethanol, all cultures were embedded in Epon epoxy resin. Semi-thin and ultra-thin sections were then cut with an ultramicrotome. Ultra-thin sections were stained with uranyl acetate and lead citrate and examined with a transmission electron microscope (TEM) (JEM-1010, JEOL, Japan).

Caspase-3/7, -8, and -9 activity assays. Caspase activity was measured using Caspase-Glo 3/7, 8 and 9 assay kits (Promega, Madison, WI). Cells were seeded at $1 \times 10^{4}$ cells/well in 96-well, white-walled plates and treated with 125,250 or $500 \mu \mathrm{M}$ TMZ, or DMSO after cells were grown to $50 \%$ confluence. After incubation for $0,2,4,8,12$ or $24 \mathrm{~h}$, an equal volume of Caspase-Glo reagent was added. The plates were shaken at 500 $\mathrm{rpm}$ for $30 \mathrm{sec}$, incubated for $1 \mathrm{~h}$, and measured for luminescent output (relative light units, RLU) using a Veritas Microplate Luminometer (Turner BioSystem, Sunnyvale, CA). Data are presented as the mean \pm SD from three replicates.

Western blotting. Analysis of the expression of Bcl-2 and poly(ADP-ribose) polymerase (PARP) (intact and cleaved fragments) was performed after TMZ $(250 \mu \mathrm{M})$ treatment for $0,4,8,12,24 \mathrm{~h}, 48$ or $72 \mathrm{~h}$. Briefly, cell lysates were separated on a $10 \%$ acrylamide gel, electrophoretically transferred onto a PVDF membrane (PALL Corp., East Hills, NY, USA) and probed by standard techniques with primary antibodies for Bcl-2 and PARP. HRP-conjugated goat anti-rabbit IgG (1:1000 
dilution, Cell Signaling Technology) was used as a secondary antibody for rabbit anti-PARP (1:1000 dilution, Cell Signaling Technology) and rabbit anti-Bcl-2 (1:1000 dilution, Santa Cruz Biotechnology, Inc., Santa Cruz, CA, USA) primary antibodies, whereas horse anti-mouse IgG (1:1000 dilution, Cell Signaling Technology) was used as a secondary antibody for the mouse anti- $\beta$-actin primary antibody (1:1000 dilution, Santa Cruz Biotechnology, Inc).

Gonadotropin secretion assay. The effects of TMZ on gonadotropin secretion were analyzed by measuring folliclestimulating hormone (FSH) and luteinizing hormone ( $\mathrm{LH})$ levels in the culture medium from $\alpha$ T3-1 cells with a Centaur ${ }^{\circledR}$ XP Immunoassay System (ADVIA) (Siemens, USA). In brief, the $\alpha \mathrm{T} 3-1$ cells were cultured in 24-well plates and treated with 125,250 or $500 \mu \mathrm{M}$ TMZ, or DMSO after cells were grown to $50 \%$ confluence. After incubation for $24,48,72$ or $144 \mathrm{~h}$, the supernatant was collected and diluted 5-fold to bring the typical hormone concentration within the middle of the standard range for the hormone assay. Results are expressed as the mean \pm SD from three independent experiments.

Statistical analysis. The normal distribution and homogeneity of variance of the data sets were analyzed by the Kolmogorov-Smirnov test and Levene's test, respectively, in advance. Comparisons of the means for cell proliferation, Annexin V Staining, Caspase-Glo assay, immunoblotting, and gona-dotropin assay for $\alpha \mathrm{T} 3-1$ cells at the examined time points for vehicle and TMZ concentrations were analyzed using one-way ANOVA. The cell cycle data for vehicle and TMZ was compared by independent-samples t-test. A P-value $<0.05$ was considered to be statistically significant.

\section{Results}

Inhibition of cell proliferation and dose response to TMZ. TMZ significantly reduced the viability of $\alpha \mathrm{T} 3-1$ cells in a concentration- and time-dependent manner following a 24-72-h treatment, as assessed by the CCK-8 assay (Fig. 1A). Cell viability decreased linearly with the increasing TMZ concentrations and the $\mathrm{IC}_{50}$ value at $72 \mathrm{~h}$ was $260.44 \mu \mathrm{M}$. The lowest examined concentration of TMZ $(31.25 \mu \mathrm{M}) \mathrm{did}$ not demonstrate a statistically significant inhibition of cell proliferation $(\mathrm{P}>0.05)$. The lowest concentration of TMZ to demonstrate an effect $(62.5 \mu \mathrm{M})$ reduced $\alpha \mathrm{T} 3-1$ cellular viability to $88.4 \pm 3.66 \%$ ( $\mathrm{P}<0.001$ vs. vehicle) following a 72-h treatment. The maximal effect was observed following a 72-h treatment with $1000 \mu \mathrm{M}$ TMZ, which remarkably dropped cellular viability to $2.4 \pm 0.67 \%$ ( $\mathrm{P}<0.001$ vs. vehicle) in the $\alpha \mathrm{T} 3-1$ cell line. TMZ treatment was also associated with obvious morphological changes in $\alpha \mathrm{T} 3-1$ cells, including cellular floating and cell debris accumulating following a 24-72-h treatment with $250 \mu \mathrm{M}$ TMZ (Fig. 1B).

TMZ induces growth arrest and apoptosis. To address whether the anti-proliferative effect of TMZ in pituitary adenoma cells is associated with cell cycle regulation, DNA cell cycle analysis was performed in $\alpha \mathrm{T} 3-1$ cells treated with TMZ or vehicle for 24 or $48 \mathrm{~h}$. Incubation with TMZ $(250 \mu \mathrm{M}$, a dose close to the $\mathrm{IC}_{50}$ value) for 24 or $48 \mathrm{~h}$ increased the
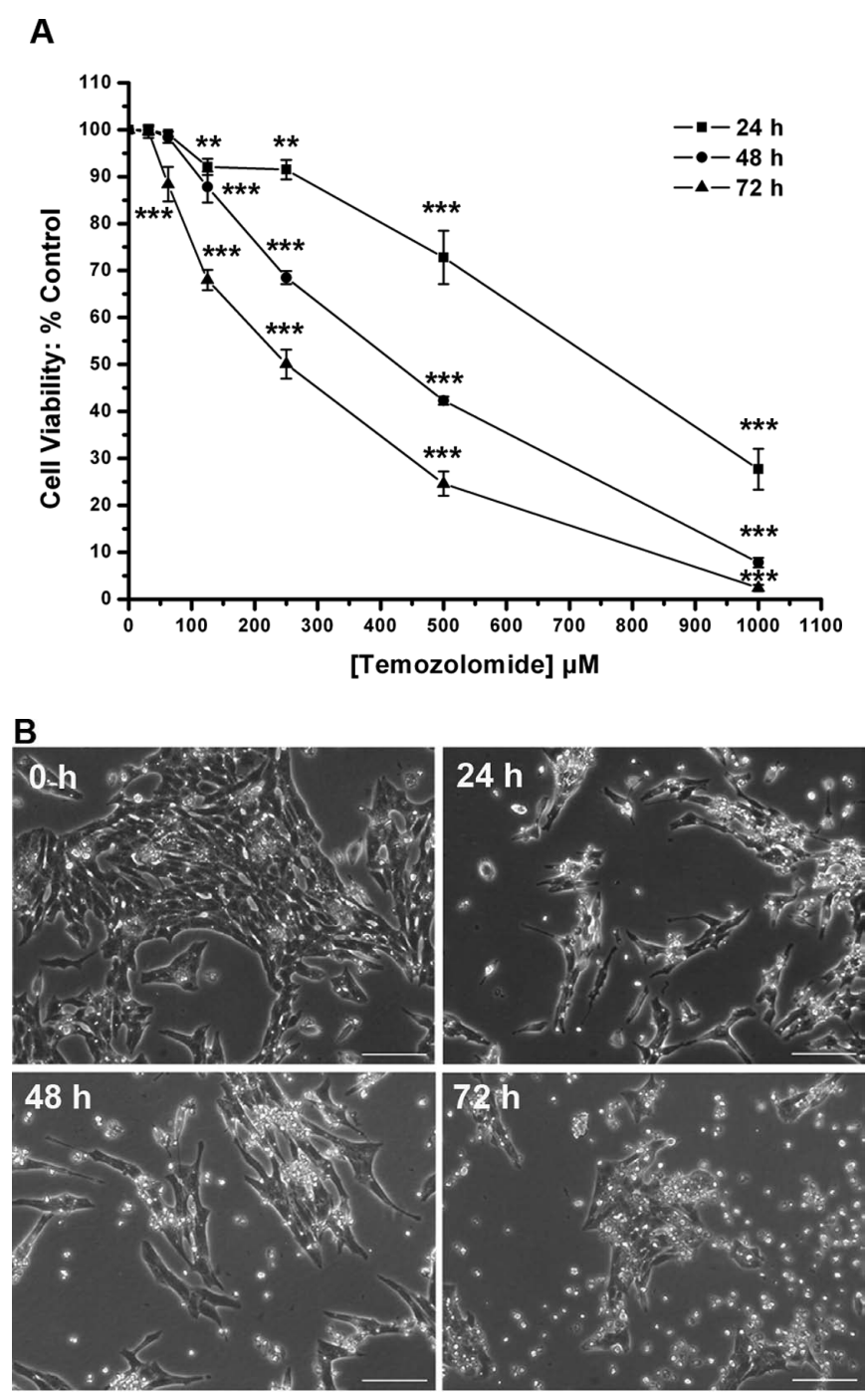

Figure 1. Effect of temozolomide (TMZ) on pituitary adenoma cellular viability. (A) TMZ (31.25-1000 $\mu \mathrm{M})$ concentration- and time-dependently reduced the viability of $\alpha \mathrm{T} 3-1$ cells following 24-72-h treatment, as assessed by CCK- 8 assay. Data are expressed as the mean \pm SD from three independent experiments and analyzed using one-way ANOVA. ${ }^{* *} \mathrm{P}<0.01,{ }^{* * *} \mathrm{P}<0.001$ vs. vehicle-treated cultures. (B) Cellular morphology of $\alpha \mathrm{T} 3-1$ cells following 0-72-h treatment with $250 \mu \mathrm{M}$ TMZ. Bars, $100 \mu \mathrm{m}$.

number of S-phase $(37.60 \pm 8.63$ vs. $21.00 \pm 2.83 \%$ in control, $\mathrm{P}<0.05$ and $33.03 \pm 6.65$ vs. $15.00 \pm 4.76 \%$ in control, $\mathrm{P}<0.05$, respectively) and $\mathrm{G} 2 / \mathrm{M}$-phase $(30.75 \pm 8.70$ vs. $11.70 \pm 3.82 \%$ in control, $\mathrm{P}<0.05$ and $29.90 \pm 9.82$ vs. $7.97 \pm 1.68 \%$ in control, $\mathrm{P}<0.05$, respectively) cells, accompanied by a corresponding decrease in the proportion of cells in G0/G1 $(31.65 \pm 10.07$ vs. $67.30 \pm 6.65 \%$ in control, $\mathrm{P}<0.01$ and $37.07 \pm 10.16$ vs. $77.03 \pm 5.67 \%$ in the control, $\mathrm{P}<0.01$, respectively) (Fig. 2).

To determine whether TMZ increased apoptotic cell death, flow cytometry analysis was performed. The percentage of early apoptotic cells (Annexin $\mathrm{V}^{+} / \mathrm{PI}^{-}$) increased from $0.27 \pm 0.10 \%$ in vehicle-treated cultures to $5.67 \pm 1.12 \%$ ( $\mathrm{P}<0.01$ vs. vehicle), $9.03 \pm 0.70 \%$ ( $\mathrm{P}<0.001$ vs. vehicle), and $18.20 \pm 2.49 \%(\mathrm{P}<0.001$ vs. vehicle) following a $24-\mathrm{h}$ treatment with 125,250 , or $500 \mu \mathrm{M}$ TMZ, respectively (Fig. 3A and B). These data suggest that both cell cycle arrest and cell apoptosis could be the reasons for the anti-proliferative effects of TMZ and may result in the inhibition of $\alpha \mathrm{T} 3-1$ cell viability. 


\section{A}
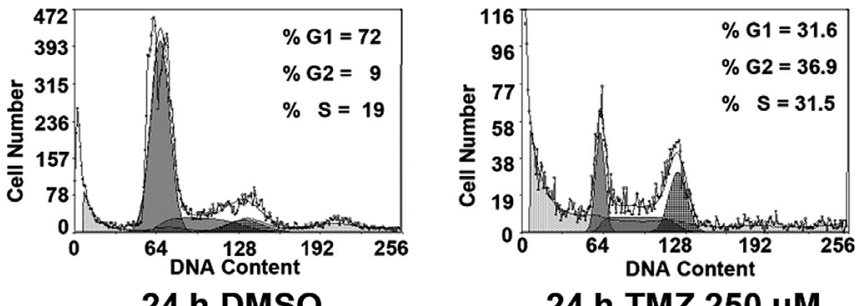

$24 \mathrm{~h}$ TMZ $250 \mu \mathrm{M}$

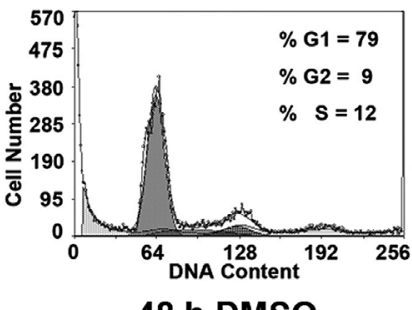

$48 \mathrm{~h}$ DMSO

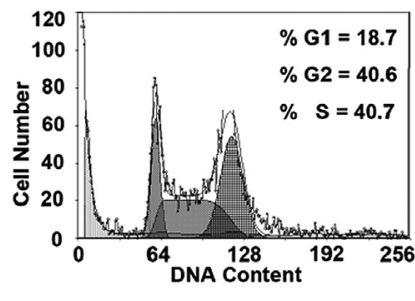

$48 \mathrm{~h} \mathrm{TMZ} 250 \mu \mathrm{M}$

B

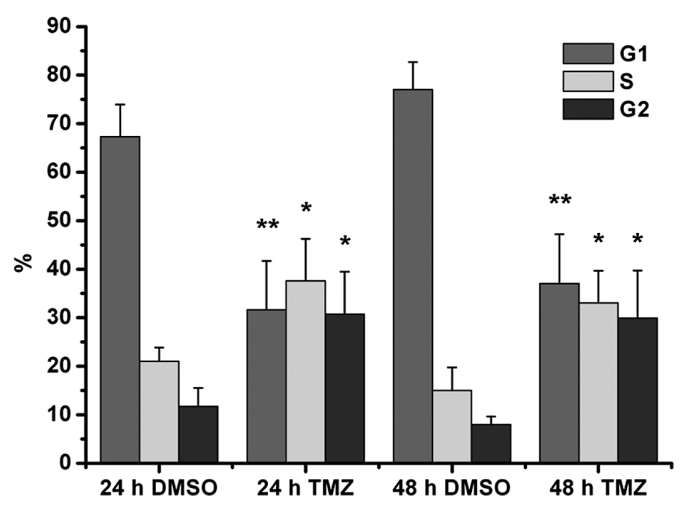

Figure 2. Cell cycle analysis of $\alpha \mathrm{T} 3-1$ cells following temozolomide (TMZ) treatment. Cells were incubated in either medium plus DMSO or medium containing TMZ $(250 \mu \mathrm{M})$ plus DMSO for $24-48 \mathrm{~h}$ before harvesting. The harvested cells were stained with propidium iodide and analyzed by fluorescence-activated cell sorting to determine the proportion of cells in each phase of the cell cycle. (A) Representative flow cytometry histograms obtained from treated cells. (B) Quantitation of cell population distribution over the various stages of the cell cycle. TMZ increased the percentage of cells in the $\mathrm{S}$ and $\mathrm{G} 2 / \mathrm{M}$ phases and decreased the percentage of cells in G0/ G1 phase of the cell cycle. Data are expressed as the mean \pm SD from the three independent experiments and analyzed using independent-samples t-test. ${ }^{*} \mathrm{P}<0.05,{ }^{* *} \mathrm{P}<0.01$ vs. vehicle-treated cultures.

The above hypotheses were further proven by visualization of apoptotic cells using TUNEL staining (Fig. 3C) and electron microscopy scaning (Fig. 3D). After TMZ (250 $\mu \mathrm{M})$ treatment for $24 \mathrm{~h}, \alpha \mathrm{T} 3-1$ cells exhibited certain morphological features of apoptosis, including nuclear shrinkage, chromatin condensation and margination.

Caspase activation and Bcl-2, PARP attenuation induced by $T M Z$. To investigate the mechanism of the proapoptotic effect of TMZ on pituitary adenoma cells, we detected the effect of TMZ on cleavage of caspases by Caspase-Glo 3/7, 8 and 9 assay. Compared with vehicle, both 250 and $500 \mu \mathrm{M}$ TMZ dramatically augmented caspase-3/7 (Fig. 4A), -8 (Fig. 4B) and -9 (Fig. 4C) activation after treatment for $2-24 \mathrm{~h}$, while $125 \mu \mathrm{M}$ induced a partial increase. Basal cellular caspase-

3/7, -8 and -9 levels were $4.95 \pm 0.16 \times 10^{3}$ RLU, $1.03 \pm 0.07 \times 10^{3}$ RLU and $3.67 \pm 0.29 \times 10^{3} \mathrm{RLU}$, respectively. The lowest tested dose of TMZ $(125 \mu \mathrm{M})$ increased caspase- $3 / 7,-8$ and -9 to $10.59 \pm 0.44 \times 10^{3} \mathrm{RLU}\left(\mathrm{P}<0.001\right.$ vs. vehicle), $1.40 \pm 0.13 \times 10^{3}$ RLU ( $\mathrm{P}>0.05$ vs. vehicle) and $5.60 \pm 0.32 \times 10^{3}$ RLU ( $\mathrm{P}<0.05$ vs. vehicle), respectively, following a 2 -h treatment. $\operatorname{TMZ}(250 \mu \mathrm{M})$ increased the level of caspase-3/-7 6-fold, caspase-9 7-fold, and caspase-8 3-fold after a 24-h incubation. A maximal effect was found following a 24-h incubation with $500 \mu \mathrm{M}$ TMZ, which significantly raised caspase $-3 / 7,-8$ and -9 to $155.65 \pm 1.56 \times 10^{3}$ RLU ( $\mathrm{P}<0.001$ vs. vehicle), $23.73 \pm 1.13 \times 10^{3}$ RLU ( $\mathrm{P}<0.001$ vs. vehicle) and $143.08 \pm 8.12 \times 10^{3}$ RLU ( $<<0.001$ vs. vehicle), respectively. These results suggest that the pro-apoptotic effect of TMZ treatment in $\alpha \mathrm{T} 3-1$ cells could be mediated by both the death receptor and the mitochondrial pathways.

To further confirm the above postulations we performed immunostaining for antiapoptotic proteins, including Bcl-2, an inner mitochondrial membrane protein that blocks apoptosis, and PARP, a nuclear polymerase involved in DNA repair, predominantly in response to environmental stress. The cleavage of the 116-89 kDa PARP by caspase-3/7 is considered to be a marker for cells undergoing apoptosis. We performed Western blot analysis to determine changes in $\mathrm{Bcl}-2$ and the cleaved form of PARP after treatment of cells with TMZ. Consistent with caspase- 9 and $-3 / 7$ activation and the increase in apoptotic cell death, TMZ $(250 \mu \mathrm{M})$ down-regulated the expression of Bcl-2 in a time-dependent manner (Fig. $5 \mathrm{~A})$. Densitometric analysis revealed a maximal reduction following a 72-h treatment, which decreased Bcl-2 expression to $46.04 \pm 12.51 \%$ ( $\mathrm{P}<0.001$ vs. control) (Fig. 5B). TMZ also raised the proteolysis of PARP following 4-72-h exposure, coinciding with $\mathrm{Bcl}-2$ attenuation, caspase activation and apoptotic cell death (Fig. 5A). These results support our belief that the mitochondrial apoptotic pathway contributes to the pro-apoptotic effect of TMZ treatment in $\alpha \mathrm{T} 3-1$ cells.

Effects of TMZ on gonadotropin secretion. To detect the functional inhibition of TMZ on the hormone secretion of $\alpha \mathrm{T} 3-1$ cells, the supernatant was examined by a Centaur ${ }^{\circledR} \mathrm{XP}$ Immunoassay System after TMZ $(125,250$ or $500 \mu \mathrm{M})$ or DMSO treatment for 24, 48, 72 and $144 \mathrm{~h}$. In agreement with the anti-proliferative effect above, both FSH (Fig. 6A) and LH (Fig. 6B) were significantly decreased by TMZ in a concentration- and time-dependent manner. Basal FSH and LH levels in the $\alpha \mathrm{T} 3-1$ cell culture medium were $10.87 \pm 1.48 \mathrm{mIU} / \mathrm{ml}$ and $1.95 \pm 0.17 \mathrm{mIU} / \mathrm{ml}$, respectively. The lowest examined dose of TMZ $(125 \mu \mathrm{M})$ reduced FSH and LH to $9.17 \pm 0.65 \mathrm{mIU} /$ $\mathrm{ml}(\mathrm{P}<0.05$ vs. vehicle) and $1.52 \pm 0.05 \mathrm{mIU} / \mathrm{ml}(\mathrm{P}<0.05$ vs. vehicle), respectively, following a $24-\mathrm{h}$ incubation. A maximal effect was found following a 144-h incubation with $500 \mu \mathrm{M}$ TMZ, which dramatically dropped FSH to $2.79 \pm 0.80 \mathrm{mIU} / \mathrm{ml}$ $(\mathrm{P}<0.001$ vs. vehicle) and $\mathrm{LH}$ to $0.41 \pm 0.05 \mathrm{mIU} / \mathrm{ml}(\mathrm{P}<0.001$ vs. vehicle), respectively.

\section{Discussion}

As the effect and mechanism of TMZ on gonadotroph adenoma cells is largely unknown, this study was performed to elucidate the mode of death of $\alpha \mathrm{T} 3-1$ cells upon treatment with TMZ. Here, we demonstrate that TMZ time- and dose- 
A

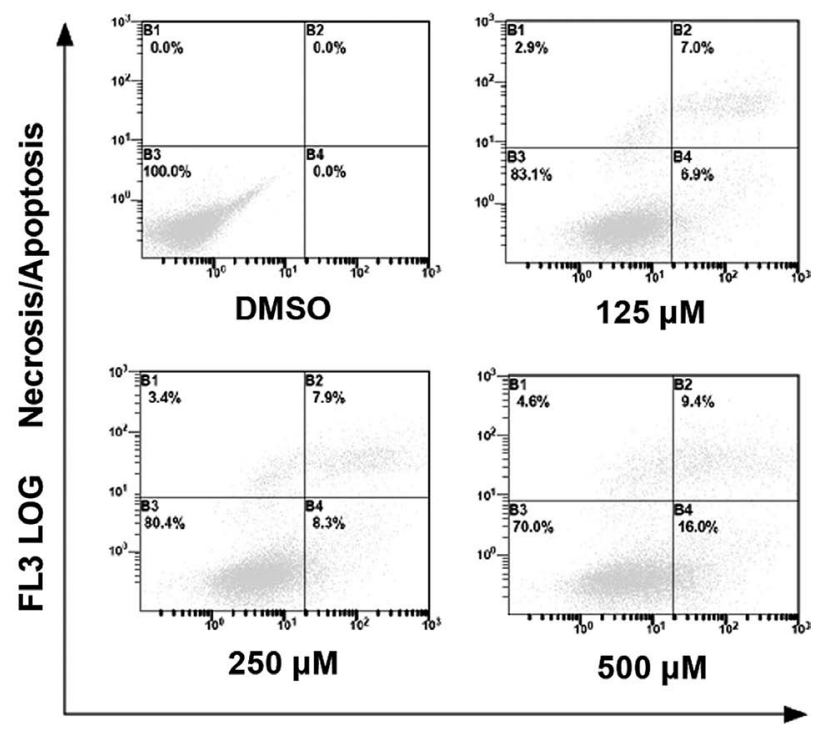

FL1 LOG Apoptosis

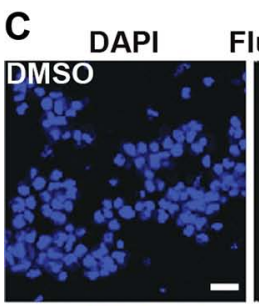

Fluorescein-12-dUTP Merged
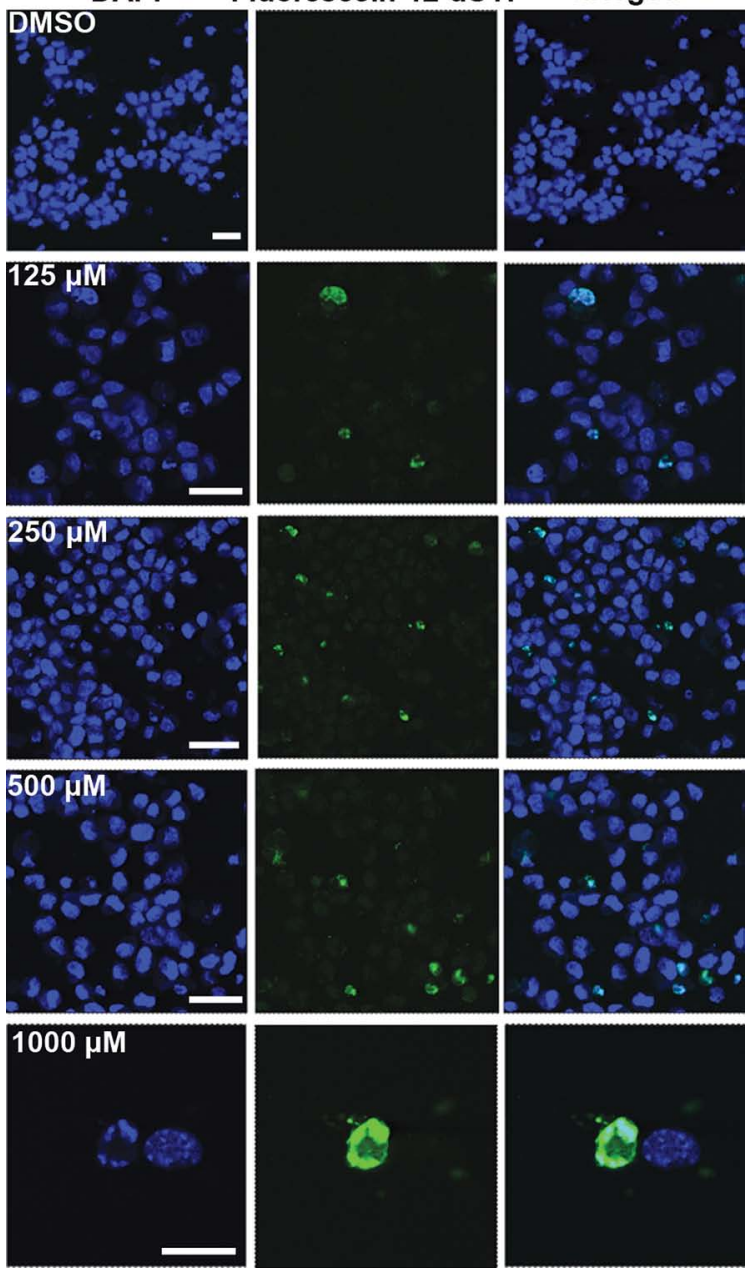

B

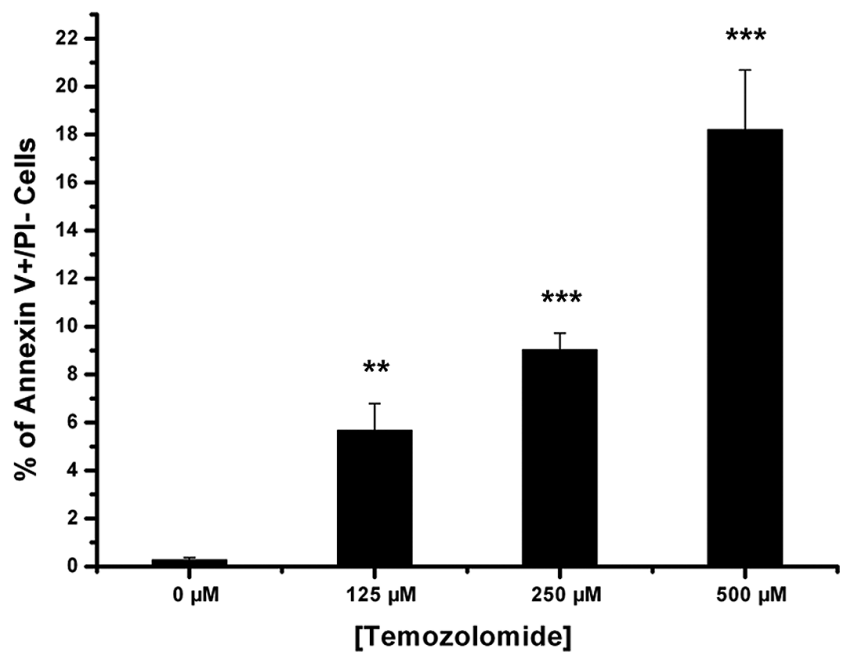

D

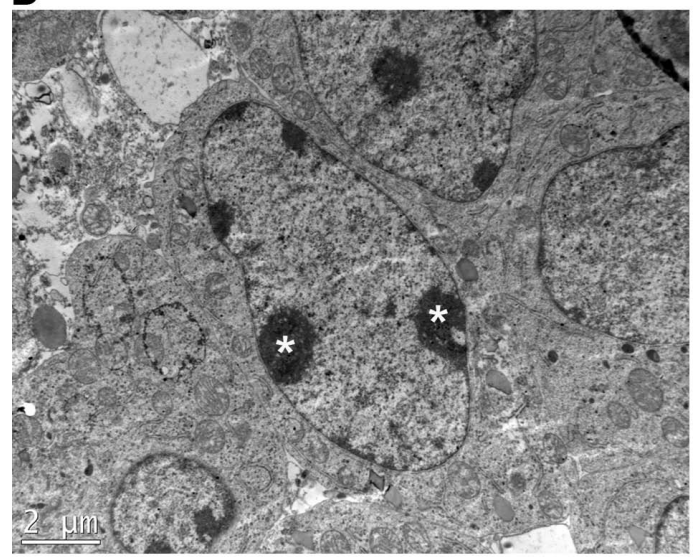

Figure 3. Temozolomide (TMZ) increases apoptotic cell death in $\alpha \mathrm{T} 3-1$ cells (A)Determination of apoptotic cell death using flow cytometry. Following $24 \mathrm{~h}$ treatment with TMZ $(125-500 \mu \mathrm{M}), \alpha \mathrm{T} 3-1$ cells were stained with PI (y-axis), and Annexin V (x-axis). The percentage of apoptotic cells was determined using a FACS flow cytometer. (B) Statistical analysis of the percentages of early apoptotic (Annexin $\mathrm{V}^{+} / \mathrm{PI}^{-}$) cells. TMZ concentrationdependently increased early apoptotic cell death in $\alpha \mathrm{T} 3-1$ cells. Data are expressed as the mean \pm SD from three independent experiments and analyzed using one-way ANOVA $\left({ }^{* *} \mathrm{P}<0.01,{ }^{* * *} \mathrm{P}<0.001\right.$ vs. vehicle). (C) Typical TUNEL staining images of nuclei of $\alpha \mathrm{T} 3-1$ cells treated by TMZ or vehicle. To identify apoptotic cells, $\alpha$ T3-1 cells were incubated for $24 \mathrm{~h}$ with various concentrations of TMZ or DMSO, and TUNEL staining was performed using the fluorometric TUNEL staining kit. Bars, $20 \mu \mathrm{m}$. (D) Typical TEM image of apoptotic $\alpha \mathrm{T} 3-1$ cells after treatment with TMZ $(250 \mu \mathrm{M})$ for $24 \mathrm{~h}$. Chromatin condensation and margination $(*)$ are present in apoptotic cells. Bars, $2 \mu \mathrm{m}$.

Among pituitary adenoma-specific chemotherapy studies, our results are consistent with previous data. Previous studies have shown that TMZ significantly inhibited cell proliferation of the somatotropin/prolactin-secreting cell line, GH3, and the prolactin-secreting cell line, MMQ, at a concentration of $250 \mu \mathrm{M}$, and similarly affected the corticotrophin-secreting dependently reduces cell viability of gonadotroph adenoma cells by inducing cell cycle arrest and apoptosis, with a parallel decrease of Bcl-2 and full-length PARP expression and increase in caspase-3/7, -8 and -9 activities. Functionally, TMZ reduced gonadotropin levels, including FSH and LH, in the cell culture supernatant. 
A

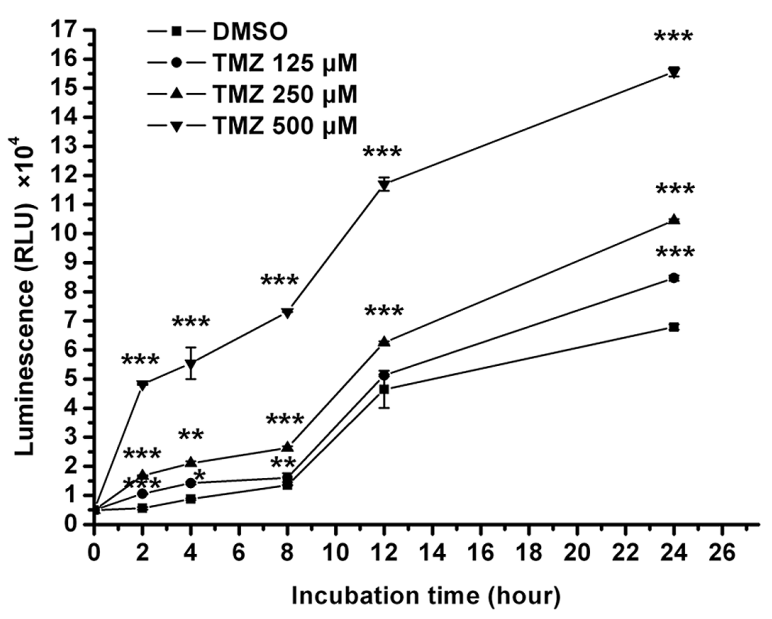

B

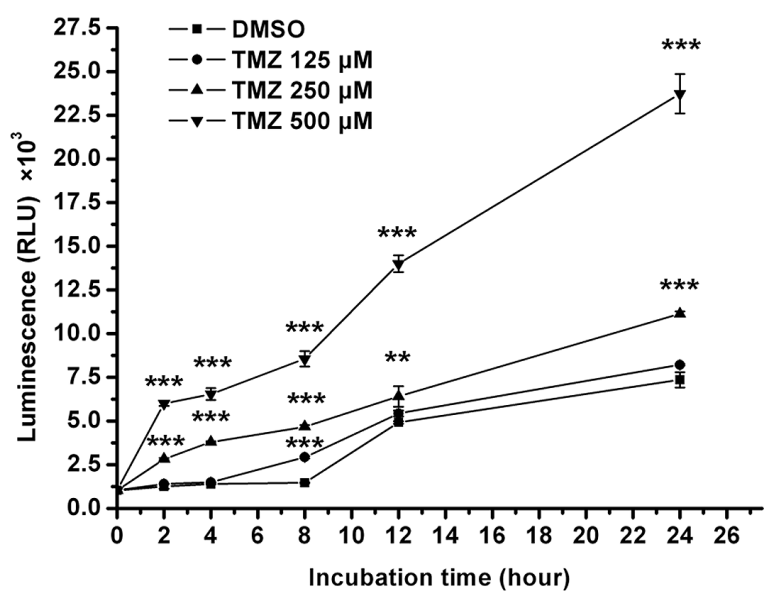

C

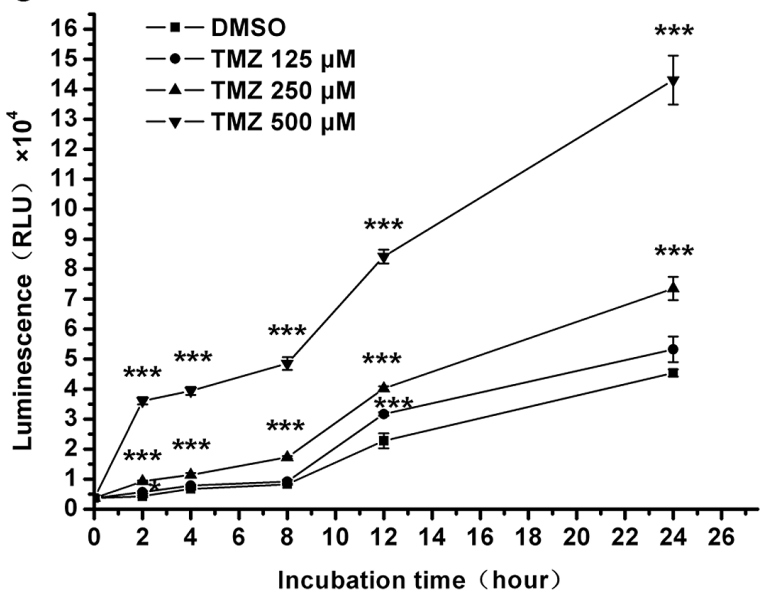

Figure 4. Temozolomide (TMZ) time- and dose-dependently enhances caspase activity in pituitary adenoma cells. To investigate the mechanism of the proapoptotic effect of TMZ on $\alpha \mathrm{T} 3-1$ cells, the activities of cellular caspase-3/7 (A), -8 (B), and -9 (C) were evaluated after treatment with TMZ $(125,250$ or $500 \mu \mathrm{M})$ or DMSO for $0,2,4,8,12$ or $24 \mathrm{~h}$ with Caspase-Glo reagent and Veritas Microplate Luminometer. Results, recorded as RLU, are expressed as the mean \pm SD from three independent experiments and were analyzed using one-way ANOVA $\left({ }^{*} \mathrm{P}<0.05,{ }^{* *} \mathrm{P}<0.01,{ }^{* * *} \mathrm{P}<0.001\right.$ vs. vehicle treated cultures).

cell line, AtT20, at a concentration of $50 \mu \mathrm{M}$ (17). In our study, the $\mathrm{IC}_{50}$ value of $\mathrm{TMZ}$ for the $\alpha \mathrm{T} 3-1$ cells was $260.44 \mu \mathrm{M}$, close to the value of $258 \mu \mathrm{M}$ reported by Sheehan et al (17).

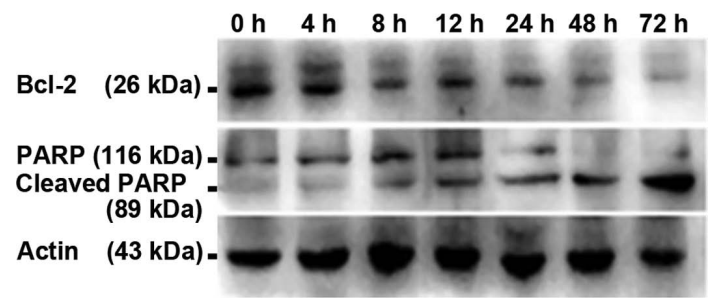

B

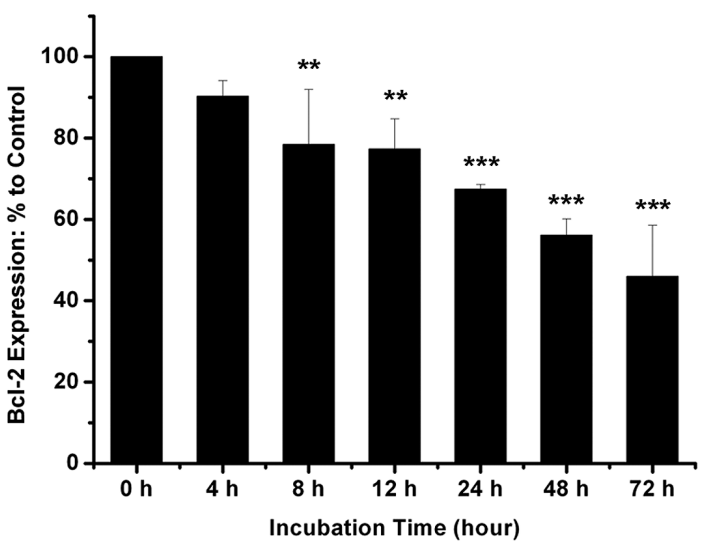

Figure 5. Temozolomide (TMZ) time-dependently attenuates the expression of anti-apoptotic proteins in pituitary adenoma cells. To evaluate the effect of TMZ on anti-apoptotic proteins, Western blot analysis of the expression of Bcl-2 and PARP (intact and cleaved fragments) was performed after TMZ $(250 \mu \mathrm{M})$ treatment of $\alpha \mathrm{T} 3-1$ cells for $0,4,8,12,24,48$ or $72 \mathrm{~h}$. (A) Representative blots of three independent experiments. $\beta$-actin was used as loading control. TMZ reduced $\mathrm{Bcl}-2$ expression and increased PARP cleavage, in agreement with capase- $8,-9$ and $-3 / 7$ activation (Fig. 4). (B) Densitometric analysis of Western blots. Data are expressed as the mean \pm SD from three independent experiments and analyzed using one-way ANOVA $\left({ }^{* *} \mathrm{P}<0.01,{ }^{* * * *} \mathrm{P}<0.001\right.$ vs. control).

This suggests that in the present experiment TMZ had comparable cytotoxicity, and that the $\alpha \mathrm{T} 3-1$ cells had acceptable TMZ sensitivity. These findings further confirm the notion that TMZ is potentially fitting for the chemotherapy of relatively slowgrowing pituitary adenomas, because it is not cell cycle-specific and restrains all phases of tumor cell growth (14).

Reports exist describing gonadotroph adenoma patients whose lesions decreased after TMZ therapy. Fadul et al (15) reported two cases of a persistent response to TMZ, one in a patient with a recurrent luteinizing hormone-secreting pituitary carcinoma, the other of a patient with hyperprolactinemia from a prolactinoma. After TMZ treatment, eradication of neck and shoulder pain, improvements in visual field deficits and tumor shrinkage were seen in the first patient, while serum prolactin concentration decreased in the second patient. The responses lasted for more than 1 year in both patients after TMZ chemotherapy. In addition, Syro et al (16) reported a case of a recurrent oncocytic gonadotropic pituitary adenoma that was partly immunopositive for $\mathrm{LH}$ and $O^{6}$-methylguanine-DNA methyltransferase (MGMT), a major determinant of resistance to some types of cytostatic treatments (10). After TMZ administration, MRI demonstrated significant tumor necrosis, indicating responsiveness to TMZ therapy. These examples demonstrate that gonadotropic pituitary adenomas may be sensitive to TMZ even when MGMT is partially immunopositive. 
A

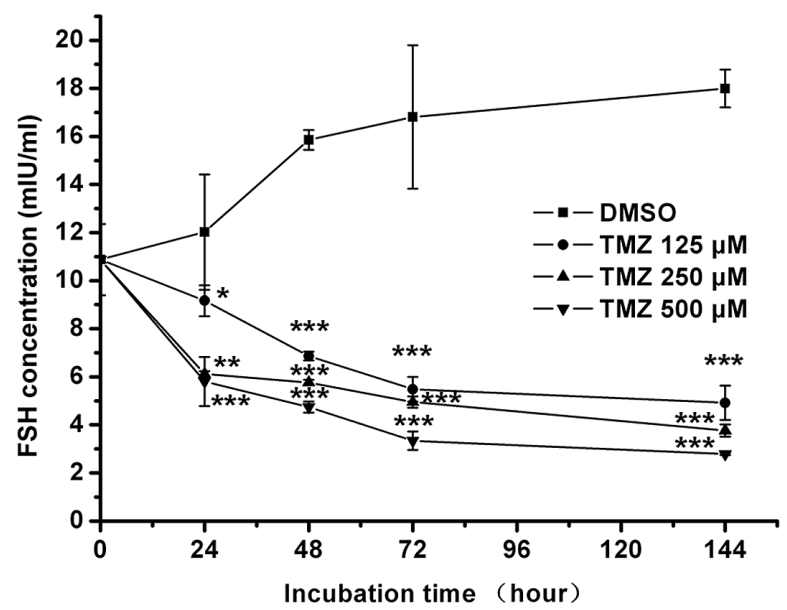

B

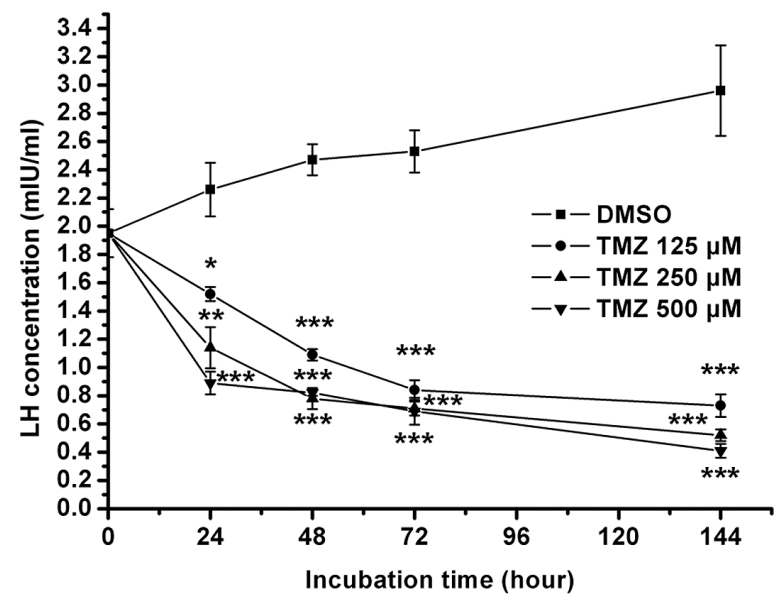

Figure 6. Effects of temozolomide (TMZ) on gonadotropin secretion. To detect the effect of TMZ on hormone secretion of $\alpha$ T3-1cells, the supernatant was examined by the Centaur ${ }^{\circledR}$ XP Immunoassay System after TMZ (125, 250 or $\left.500 \mu \mathrm{M}\right)$ or DMSO treatment for $24,48,72$ or 144 h. Both FSH (A) and LH (B) were decreased by TMZ in a time- and dose-dependent mode. Data are expressed as the mean \pm SD from three independent experiments and analyzed using one-way ANOVA $\left({ }^{*} \mathrm{P}<0.05,{ }^{* *} \mathrm{P}<0.01,{ }^{* * *} \mathrm{P}<0.001\right.$ vs. control).

Our data are also consistent with previous investigations characterizing the mechanism of action of TMZ. We have shown that TMZ induced statistically significant S-phase accumulation and G2/M-phase arrest, which suggest that a large number of cells in gonadotroph pituitary adenomas failed to complete DNA synthesis smoothly, followed by increased apoptosis. What is the mechanism by which TMZ initiates these anti-proliferative effects on pituitary adenoma cells? Kaina et al (20) proved that $O^{6}$-methylguanine $\left(O^{6} \mathrm{MeG}\right)$ is the major proapoptotic DNA lesion in malignant glioma cells upon $O^{6}$-methylating agent treatment. At a $\mathrm{pH}>7 \mathrm{TMZ}$ is transformed into 5-(3-methyl-1-triazeno)-imidazole-4-carboxamide (MTIC), which methylates DNA at the $N^{\beta}$ position of adenine and the $O^{6} \mathrm{MeG}$. During the next cycle of DNA replication, $O^{6} \mathrm{MeG}$ mismatches with thymine (21), which is recognized and degraded by a mismatch repair system (MMR) (22). Owing to the template strand location of the adduct, another thymidine residue will replace the mismatched one during repair synthesis. Double-strand breaks (DSBs) in the DNA are generated due to repeated and invalid attempts to repair the damage, which then activates cell cycle checkpoints, G2/M cell cycle arrest and apoptosis through a signaling cascade $(8,23)$. In addition to $O^{6} \mathrm{MeG}$, the $N^{3}$-methyladenine adduct exerts its cytotoxic effect by hindering the binding of DNA polymerase to the adenine in the DNA template strand and is repaired by the base excision repair system (BER) $(21,24)$. PARP plays an important role in this repair system and cleavage of full-length PARP to the cleaved form by executioner caspase-3/7 facilitates cellular disassembly, namely cell apoptosis (25), which is in agreement with the results of our study with TMZ treatment.

How does $O^{6} \mathrm{MeG}$-triggered apoptosis get carried out in pituitary adenoma cells? After TMZ treatment, $\alpha \mathrm{T} 3-1$ cells presented the decline in Bcl-2, a hallmark of $O^{6} \mathrm{MeG}-$ triggered apoptosis (26), accompanied by caspase-9 activation and the activation of the executioner caspase-3/7. Meanwhile, caspase-8, the initiator caspase of death receptor apoptotic pathway, was also evoked. These data indicate that both death receptor and mitochondrial apoptotic pathways likely partici- pate in TMZ-induced $\alpha \mathrm{T} 3-1$ cell apoptosis. Moreover, statistical analysis indicates that the death receptor pathway is less efficiently evoked than the mitochondrial apoptotic pathway in this process. Similarly, it has been shown that $O^{6} \mathrm{MeG}$-triggered malignant glioma cell apoptosis was followed by Fas/CD95/ Apo-1 receptor and caspase-8 activation in non-p53-mutated glioma cells, and intrinsic mitochondrial apoptotic pathway activation in p53 mutated glioma cells via Bcl-2 degradation, activation of caspase-9, -7 and -3 and formation of DSBs (27).

Baseline concentrations of gonadotropin are elevated in $30-50 \%$ of gonadotroph adenoma patients, and may result in ovarian hyperstimulation and dysgenesia (28-31). In previous clinical treatment of gonadotroph adenoma patients with TMZ, changes in gonadotropin levels before and after drug administration were not evaluated $(15,16)$. In our in vitro study using gonadotroph adenoma $\alpha \mathrm{T} 3-1$ cells, TMZ resulted in a dramatic decrease in gonadotropin production, which could have clinical significance for those patients suffering from hormone-hypersecreting and invasive gonadotroph adenomas. Similarly, for hyperprolactinemia, a previous in vitro study showed that prolactin secretion in the prolactin-secreting MMQ and GH3 cell lines was inhibited by TMZ (17) and a clinical trial demonstrated that a PRL carcinoma patient presented with reduced hormone secretion and obvious tumor shrinkage after TMZ treatment (12).

It is necessary to note that the $\alpha \mathrm{T} 3-1$ cell line is not representative of human pituitary adenomas, and its human counterpart is needed to further evaluate the therapeutic effects of TMZ. In addition, the minimum stably effective concentration of TMZ $(250 \mu \mathrm{M})$ in this study is above that reasonably achievable clinically $(100 \mu \mathrm{M})(32)$. This may help explain why some patients with invasive pituitary adenoma are resistant to TMZ alone (18) and rapidly respond to the combination chemotherapy regimen of TMZ and capecitabine (33). Meanwhile, some caution must be exercised in extrapolating these results to the in vivo situation.

In summary, we report for the first time the inhibitory effects of TMZ on gonadotroph adenoma cell viability and 
hormone secretion in vitro and provide further insight into the possible mechanisms triggered by both mitochondrial and death receptor apoptosis pathways. Our results suggest that TMZ may be useful in the treatment of aggressive gonadotroph adenomas, although its in vivo efficacy has yet to be fully examined.

\section{Acknowledgements}

The authors wish to thank Dr P.L. Mellon for providing the aT3-1 cell line and the National Natural Science Foundation of China for financial support. We thank the Peking University Stem Cell Research Center and Professor Lingsong Li, Professor Li Shen, Dr Weihua Wu, Dr Lin Dong for their generous technical support and supply of reagents.

\section{References}

1. Selman WR, Laws ER Jr, Scheithauer BW and Carpenter SM The occurrence of dural invasion in pituitary adenomas. J Neurosurg 64: 402-407, 1986.

2. Asa SL and Ezzat S: The pathogenesis of pituitary tumours. Nat Rev Cancer 2: 836-849, 2002.

3. Korbonits M and Carlsen E: Recent clinical and pathophysiological advances in non-functioning pituitary adenomas. Horm Res 71 (Suppl 2): 123-130, 2009.

4. Ho DM, Hsu CY, Ting LT and Chiang H: The clinicopathological characteristics of gonadotroph cell adenoma: a study of 118 cases. Hum Pathol 28: 905-911, 1997.

5. Snyder PJ: Gonadotroph cell adenomas of the pituitary. Endocr Rev 6: 552-563, 1985.

6. Delellis RA,Lloyd RV, Heitz PU and Eng C: Pathology and genetics of tumours of endocrine organs. World Health Organization, IARC Press, Lyon, pp270-311, 2004.

7. Chanson P: Gonadotroph pituitary adenomas. Ann Endocrinol (Paris) 61: 258-268, 2000.

8. Bei R, Marzocchella L and Turriziani M: The use of temozolomide for the treatment of malignant tumors: clinical evidence and molecular mechanisms of action. Recent Pat Anticancer Drug Discov 5: 172-187, 2010.

9. Kulke MH, Chan JA, Meyerhardt JA, et al: A prospective phase II study of 2-methoxyestradiol administered in combination with bevacizumab in patients with metastatic carcinoid tumors. Cancer Chemother Pharmacol: [Epub ahead of print October 20 2010. doi: 10.1007/s00280-010-1478-7].

10. Syro LV, Ortiz LD, Scheithauer BW, et al: Treatment of pituitary neoplasms with temozolomide: a review. Cancer 117: 454-462, 2010.

11. Bush ZM, Longtine JA, Cunningham T, et al: Temozolomide treatment for aggressive pituitary tumors: correlation of clinical outcome with O(6)-methylguanine methyltransferase (MGMT) promoter methylation and expression. J Clin Endocrinol Metab 95: E280-E290, 2010.

12. Raverot G, Sturm N, de Fraipont F, et al: Temozolomide treatment in aggressive pituitary tumors and pituitary carcinomas: a French multicenter experience. J Clin Endocrinol Metab 95: 4592-4599, 2010.

13. Mohammed S, Kovacs K, Mason W, Smyth H and Cusimano MD: Use of temozolomide in aggressive pituitary tumors: case report. Neurosurgery 64: E773-E774, 2009.

14. Lim S, Shahinian H, Maya MM, Yong W and Heaney AP: Temozolomide: a novel treatment for pituitary carcinoma. Lancet Oncol 7: 518-520, 2006

15. Fadul CE, Kominsky AL, Meyer LP, et al: Long-term response of pituitary carcinoma to temozolomide. Report of two cases. J Neurosurg 105: 621-626, 2006.
16. Syro LV, Scheithauer BW, Ortiz LD, et al: Effect of temozolomide in a patient with recurring oncocytic gonadotrophic pituitary adenoma. Hormones (Athens) 8: 303-306, 2009.

17. Sheehan J, Rainey J, Nguyen J, Grimsdale R and Han S: Temozolomide-induced inhibition of pituitary adenoma cells. J Neurosurg 114: 354-358, 2011.

18. Morin E, Berthelet F, Weisnagel J, Bidlingmaier M and Serri O: Failure of temozolomide and conventional doses of pegvisomant to attain biochemical control in a severe case of acromegaly. Pituitary: [Epub ahead of print April 21, 2010. doi: 10.1007] s11102-010-0232-9].

19. Windle JJ, Weiner RI and Mellon PL: Cell lines of the pituitary gonadotrope lineage derived by targeted oncogenesis in transgenic mice. Mol Endocrinol 4: 597-603, 1990.

20. Kaina B, Fritz G, Mitra S and Coquerelle T: Transfection and expression of human O6-methylguanine-DNA methyltransferase (MGMT) cDNA in Chinese hamster cells: the role of MGMT in protection against the genotoxic effects of alkylating agents. Carcinogenesis 12: 1857-1867, 1991

21. Villano JL, Seery TE and Bressler LR: Temozolomide in malignant gliomas: current use and future targets. Cancer Chemother Pharmacol 64: 647-655, 2009.

22. Pepponi R, Marra G, Fuggetta MP, et al: The effect of O6-alkylguanine-DNA alkyltransferase and mismatch repair activities on the sensitivity of human melanoma cells to temozolomide, 1,3-bis(2-chloroethyl)1-nitrosourea, and cisplatin. J Pharmacol Exp Ther 304: 661-668, 2003.

23. D'Atri S, Tentori L, Lacal PM, et al: Involvement of the mismatch repair system in temozolomide-induced apoptosis. Mol Pharmacol 54: 334-341, 1998.

24. Tisdale MJ: Antitumour imidazotetrazines-XI: effect of 8-carbamoyl-3-methylimidazo[5,1-d]-1,2,3,5-tetrazin-4(3H)-one [CCRG 81045; $\mathrm{M}$ and B 39831 NSC 362856] on poly(ADPribose) metabolism. Br J Cancer 52: 789-792, 1985.

25. Oliver FJ, de la Rubia G, Rolli V, Ruiz-Ruiz MC, de Murcia G and Murcia JM: Importance of poly(ADP-ribose) polymerase and its cleavage in apoptosis. Lesson from an uncleavable mutant. J Biol Chem 273: 33533-33539, 1998.

26. Ochs K and Kaina B: Apoptosis induced by DNA damage O6-methylguanine is Bcl-2 and caspase-9/3 regulated and Fas/ caspase-8 independent. Cancer Res 60: 5815-5824, 2000.

27. Roos WP, Batista LF, Naumann SC, et al: Apoptosis in malignant glioma cells triggered by the temozolomide-induced DNA lesion O6-methylguanine. Oncogene 26: 186-197, 2007.

28. Djerassi A, Coutifaris C, West VA, et al: Gonadotroph adenoma in a premenopausal woman secreting follicle-stimulating hormone and causing ovarian hyperstimulation. J Clin Endocrinol Metab 80: 591-594, 1995.

29. Catargi B, Felicie-Dellan E and Tabarin A: Comment on gonadotroph adenoma causing ovarian hyperstimulation. J Clin Endocrinol Metab 84: 3404, 1999.

30. Murata Y, Ando H, Nagasaka T, et al: Successful pregnancy after bromocriptine therapy in an anovulatory woman complicated with ovarian hyperstimulation caused by follicle-stimulating hormone-producing plurihormonal pituitary microadenoma. J Clin Endocrinol Metab 88: 1988-1993, 2003.

31. Murakami T, Higashitsuji H, Yoshinaga K, Terada Y, Ito K and Ikeda $\mathrm{H}$ : Management of ovarian hyperstimulation due to follicle-stimulating hormone-secreting gonadotroph adenoma. BJOG 111: 1297-1300, 2004

32. Hammond LA, Eckardt JR, Kuhn JG, et al: A randomized phase I and pharmacological trial of sequences of 1,3-bis(2chloroethyl)-1-nitrosourea and temozolomide in patients with advanced solid neoplasms. Clin Cancer Res 10: 1645-1656, 2004.

33. Thearle MS, Freda PU, Bruce JN, Isaacson SR, Lee Y and Fine RL: Temozolomide (Temodar(R)) and capecitabine $(\mathrm{Xeloda}(\mathrm{R}))$ treatment of an aggressive corticotroph pituitary tumor. Pituitary: [Epub ahead of print December 4, 2009. doi: 10.1007/s11102-009-0211-1]. 